\title{
Anemia of Chronic Disease in Ankylosing Spondylitis: Improvement Following Anti-TNF Therapy
}

\author{
Ankilozan Spondilitte Kronik Anemi Hastalığı: Anti-TNF Tedavisini Takiben İyileşme
}

\author{
Ki-Jo KIM, Chul-Soo CHO \\ Department of Internal Medicine, Yeouido St. Mary's Hospital, The Catholic University of Korea, \\ Division of Rheumatology, Seoul, Korea
}

Objectives: We assessed the prevalence of anemia at the initiation time of anti-tumor necrosis factor (anti-TNF) therapy and the change of hemoglobin level following anti-TNF therapy in ankylosing spondylitis (AS).

Patients and methods: Forty-three patients with AS, who received anti-TNF agents, were retrospectively analyzed in the study. Hemoglobin, erythrocyte sedimentation rate (ESR), C-reactive protein (CRP), ferritin, and Bath Ankylosing Spondylitis Disease Activity Index (BASDAl) scores were evaluated at baseline and at 32 weeks following antiTNF therapy. Anemia was defined as a hemoglobin level $<12 \mathrm{mg} / \mathrm{dL}$ for women and $<13 \mathrm{mg} / \mathrm{dL}$ for men. Serum ferritin $\geq 60 \mathrm{ng} / \mathrm{ml}$ suggested anemia of chronic disease, whereas ferritin $<60 \mathrm{ng} / \mathrm{ml}$ suggested iron deficiency anemia (IDA).

Results: Anemia was found in 12 of 43 (27.9\%) AS patients at baseline. Four of 12 anemic patients indicated anemia of chronic disease (33.3\%), whereas eight indicated IDA $(66.7 \%)$. At 32 months following anti-TNF therapy, the mean hemoglobin level was improved (from $13.8 \pm 1.7$ to $14.3 \pm 1.6 \mathrm{mg} / \mathrm{dl}, \mathrm{p}=0.001$ ) along with decline of $E S R, C R P$, and BASDAI (all, $p<0.001$ ). Improvement of hemoglobin level showed positive correlation with the change of ESR and CRP $(r=0.608, p<0.001$ and $r=0.588, p<0.001$, respectively). In multivariate analysis, the change of ESR and CRP were associated independently with improvement of hemoglobin level. Recovery from anemia was significant in patients with anemia of chronic disease $(p=0.01)$, whereas not significant in patients with IDA $(p=0.079)$.

Conclusion: Anemia is not uncommon in AS patients. Improvement of hemoglobin level is observed with effective treatments in patients with AS. Anti-TNF therapy is more effective with improvement of hemoglobin than diseasemodifying antirheumatic drugs (DMARDs), especially in patients with anemia of chronic disease.

Key words: Anemia of chronic disease; ankylosing spondylitis; tumor necrosis factor.
Amaç: Bu çalışmada ankilozan spondilitte (AS) anti-tümör nekroz faktör (anti-TNF) tedavisine başlarken anemi insidansı ve anti-TNF tedavisini takiben hemoglobin düzeyinde görülen değişiklikler değerlendirildi.

Hastalar ve yöntemler: Çalışmada anti-TNF tedavisi uygulanan 43 AS hastası retrospektif olarak değerlendirildi. Hemoglobin, eritrosit sedimentasyon oranı (ESR), C-reaktif protein (CRP), ferritin ve Bath Ankilozan Spondilit Hastalık Aktivite İndeksi (BASDAI) skorları başlangıçta ve antiTNF tedavisini takiben 32. haftada değerlendirildi. Anemi, kadınlarda $<12 \mathrm{mg} / \mathrm{dL}$; erkeklerde ise $<13 \mathrm{mg} / \mathrm{dL}$ hemoglobin düzeyi olarak tanımlandı. Serum ferritin $\geq 60 \mathrm{ng} / \mathrm{mL}$ kronik anemi hastalığını gösterirken, ferritin $<60 \mathrm{ng} / \mathrm{mL}$ ise demir eksikliği anemisi (DEA)'ni gösteriyordu.

Bulgular: Başlangıçta 43 AS hastasının 12'sinde (\%27.9) anemi saptandı. On iki anemik hastanın dördünde (\%33.3) kronik anemi hastalığı, sekizinde (\%66.7) ise DEA mevcuttu. Anti-TNF tedavisinin 32. haftasında, ESR, CRP ve BASDAI skorlarında düşüş ile birlikte (tümü için $p<0.001$ ), ortalama hemoglobin düzeyinde iyileşme (13.8 $\pm 1.7 \mathrm{mg} / \mathrm{dL}$ 'den 14.3 \pm 1.6 mg'ye; $p=0.001$ ) görüldü. Hemoglobin düzeyindeki iyileşme, ESR ve CRP düzeyinde görülen değişiklik ile pozitif korelasyon gösterdi (sırasıyla $r=0.608, p<0.001$ ve $r=0.588$; $\mathrm{p}<0.001)$. Çok değişkenli analizde, ESR ve CRP düzeyinde görülen değişiklikler, hemoglobin düzeyinde iyileşme ile bağımsız bir şekilde ilişkilendirildi. Kronik anemi hastalığı olan hastalarda anemi önemli düzeyde iyileşirken $(p=0.01)$, DEA olan hastalarda anlamlı düzeye ulaşmadı $(p=0.079)$.

Sonuç: Anemi, AS hastalarında sıkça görülür. Bu hastalarda etkili tedaviler ile hemoglobin düzeylerinde iyileşme sağlanabilmektedir. Daha önceki hastalık modifiye edici anti-romatizma ilaç (DMARD) tedavisine kıyasla, anti-TNF tedavisi, özellikle kronik anemi hastalığı olan hastalarda hemoglobin düzeyinde iyileşme ile daha etkilidir.

Anahtar sözcükler: Kronik anemi hastalığı; ankilozan spondilit; tümör nekroz faktörü.

Received: November 24, 2011 Accepted: January 30, 2012

Correspondence: Ki-Jo Kim, M.D. Department of Internal Medicine, Yeouido St. Mary's Hospital, The Catholic University of Korea, Division of Rheumatology, Seoul, Korea. Tel: +82 237791093 e-mail: md21c@catholic.ac.kr

(C)2012 Turkish League Against Rheumatism. All rights reserved. 
Anemia of chronic disease (ACD), also known as anemia of inflammation, is a hypoproliferative anemia that develops in response to systemic illness or inflammation such as infection, cancer, and autoimmune conditions. ${ }^{[1]}$ Although ACD is the second most prevalent type of anemia after that caused by iron deficiency, it is the most common among patients with chronic illness. ${ }^{[2]}$ However, precise estimates of prevalence are difficult to determine because many patients with anemia are not investigated sufficiently to establish the cause. ${ }^{[3]}$

Anemia is the most frequent extra-articular manifestation of rheumatoid arthritis (RA) and is estimated to occur in $30 \%$ to $60 \%$ of patients. ${ }^{[4,5]}$ Of the group classified as anemic, $77 \%$ were found to have ACD and $23 \%$ to have iron deficiency anemia (IDA). ${ }^{[6]}$ Rheumatoid arthritis patients with anemia have evidence of more severe disease, with more involved joints and higher levels of functional disability and pain. ${ }^{[6,7]}$ Moreover, anemia usually causes symptoms and signs like fatigue, impaired cognitive function, anorexia, exertional dyspnea, and loss of libido when the oxygen carrying capacity of the blood is unable to meet the oxygen requirements of body tissues. Therefore, it is generally accepted that the symptoms of anemia adversely affect quality of life, even when it is a mild form. ${ }^{[7,8]}$

Ankylosing spondylitis (AS) is a chronic, progressive disease characterized by inflammation of entheses, leading to new bone formation, syndesmophytes, and ankylosis of joints, primarily in the axial skeleton. ${ }^{[9]}$ Patients with AS often have associated peripheral arthritis, enthesitis, osteoporosis, or extraarticular involvement such as uveitis, psoriasis, or inflammatory bowel disease. ${ }^{[10]}$ Anemia can also occur in AS patients and significantly affect a patient's quality of life. However, the exact prevalence and incidence of anemia in patients with AS remains unknown, and the clinical significance has so far not been assessed.
Tumor necrosis factor-alpha (TNF- $\alpha$ ), one of the proinflammatory cytokines, plays a major role in the pathogenesis of ACD through its inhibitory effects on erythropoiesis and iron release from the reticuloendothelial system. ${ }^{[1]}$ It also is implicated in the pathogenesis of AS. ${ }^{[1]]}$ Therefore, we investigated the prevalence of anemia at the initiation of anti-TNF therapy and the changes in hemoglobin levels with anti-TNF therapy in AS according to types of anemia.

\section{PATIENTS AND METHODS}

\section{Patients}

A total of 43 patients with AS who were diagnosed between 2002 to 2007 at Yeouido St. Mary's Hospital, The Catholic University of Korea were included in this study and examined in a retrospective manner. All patients were over 20 years of age, fulfilled the modified New York criteria for the diagnosis of AS, ${ }^{[12]}$ and fulfilled the criteria for anti-TNF- $\alpha$ treatment according to the Assessments in Ankylosing Spondylitis (ASAS) consensus statement. ${ }^{[13]}$ All patients were treated initially with non-steroidal anti-inflammatory drugs (NSAIDs) and/or disease-modifying antirheumatic drugs (DMARDs), such as sulfasalazine (SSZ) and methotrexate (MTX), for at least three months and showed good response to this conventional therapy. After a period of time (24.0 \pm 19.7 months), the disease was activated again [using a Bath Ankylosing Spondylitis Disease Activity Index (BASDAI) score $\geq 4$ ], and anti-TNF therapy was begun. The study outline is illustrated in Figure 1. Excluded were patients with the concomitant presence of inflammatory bowel disease, chronic renal or hepatic disease, diabetes mellitus, hematologic diseases, thyroid diseases, malnutrition, or a drug intake which affected erythropoiesis (alkylating agents, sulfonamides, or anticonvulsants). Patients who showed evidence of malnutrition, gastrointestinal bleeding, or acute infection based on the medical records were also excluded. The study was approved

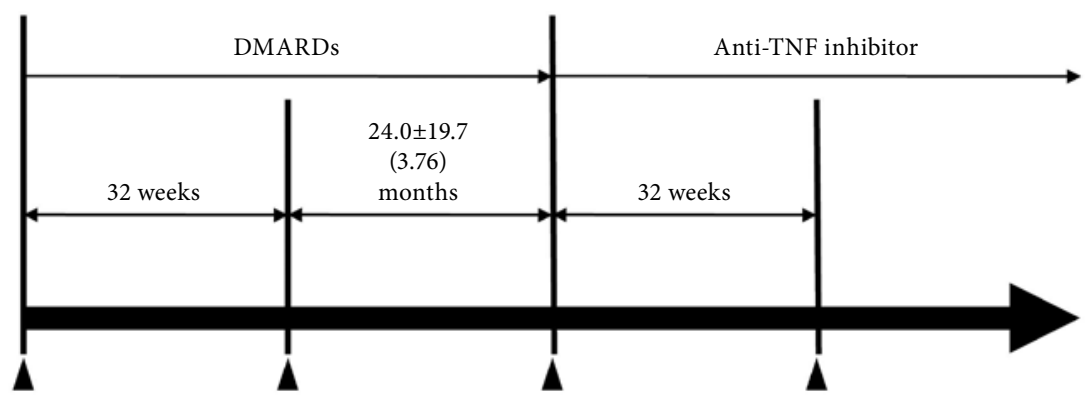

Figure 1. Illustration of study outline. Values are expressed as mean \pm standard deviation (minimun, maximum) unless otherwise stated. 
by the Institutional Review Board, Clinical Research Coordinating Center of the Catholic Medical Center and was conducted in accordance with the Declaration of Helsinki.

\section{Clinical and laboratory analysis}

Complete medical records and laboratory tests were thoroughly reviewed. The hemoglobin levels, erythrocyte sedimentation rates (ESR), C-reactive protein (CRP), ferritin, and BASDAI were evaluated at baseline and week 32 of the anti-TNF therapy. Anemia was defined using the World Health Organization criteria of a hemoglobin level less than $12 \mathrm{gm} / \mathrm{dl}$ for women and $13 \mathrm{gm} / \mathrm{dl}$ for men. ${ }^{[14]}$ On the basis of previously reported data, serum ferritin equal to or higher than $60 \mathrm{ng} / \mathrm{ml}$ indicated ACD, whereas ferritin below $60 \mathrm{ng} / \mathrm{ml}$ indicated IDA. ${ }^{[15,16]}$

\section{Statistics}

The results were presented as mean \pm standard deviation for continuous data and as a percentage for categorical data. Comparisons of the numerical data between groups were performed by the Student's t-test or Mann-Whitney U-test. Pearson's correlation coefficients were used, when appropriate, to analyze the relationship between the ESR, CRP and hemoglobin. A multiple linear regression model that included age, sex, disease duration, type of anti-TNF agents, and changes in the ESR, CRP and BASDAI scores was used to evaluate the independent effect of clinical and laboratory variables on the improvement in hemoglobin levels. $\mathrm{P}$ values less than 0.05 were considered statistically significant.

\section{RESULTS}

\section{Baseline characteristics}

The baseline demographics and disease characteristics of the AS patients in our study are shown in Table 1. The mean age of the population was $37.3 \pm 7.9$ years, and the mean disease duration was $5.1 \pm 3.4$ years. All patients were treated initially with NSAIDs and/or DMARDs for a mean of $31.9 \pm 20.0$ months before the beginning of anti-TNF therapy and showed positive responses to this conventional therapy. Anti-TNF therapy was determined when reactivation of the disease activity (by BASDAI score $\geq 4$ ) was verified. Administration of NSAIDs was maintained for all of the patients except two because these showed poor adherence to oral medication.

\section{Prevalence of anemia at the initiation of anti-TNF therapy}

Anemia was defined on the basis of the WHO criteria. ${ }^{[14]}$ Of 43 patients, twelve (6 males and 6 females) were found to have anemia (27.9\%), and the mean

\begin{tabular}{|c|c|c|c|}
\hline \multirow[t]{2}{*}{ Variable } & \multicolumn{3}{|c|}{ Value } \\
\hline & $\mathrm{n}$ & $\%$ & Mean \pm SD \\
\hline Age, years & & & $37.3 \pm 7.9$ \\
\hline \multicolumn{4}{|l|}{ Sex } \\
\hline Male & 35 & 81.4 & \\
\hline Female & 8 & 18.6 & \\
\hline Disease duration (years) & & & $5.14 \pm 3.4$ \\
\hline HLA-B27 positivity & 37 & 86.0 & \\
\hline \multicolumn{4}{|l|}{ Drugs before anti-TNF therapy } \\
\hline NSAIDs & 1 & 2.3 & \\
\hline NSAIDs + sulfasalazine & 9 & 20.9 & \\
\hline NSAIDs + sulfasalazine + methotrexate & 33 & 76.7 & \\
\hline \multicolumn{4}{|l|}{ Duration of DMARD treatment } \\
\hline before anti-TNF therapy (months) & & & $31.9 \pm 20.0$ \\
\hline Anemia & 12 & 27.9 & \\
\hline Anemia of chronic disease & 4 & 9.3 & \\
\hline Iron deficiency anemia & 8 & 18.6 & \\
\hline \multicolumn{4}{|l|}{ Anti-TNF inhibitors } \\
\hline Etanercept & 26 & 60.4 & \\
\hline Infliximab & 14 & 32.6 & \\
\hline Adalimumab & 3 & 7.0 & \\
\hline
\end{tabular}


Table 2. Clinical and laboratory response to anti-TNF therapy at week 32

\begin{tabular}{|c|c|c|c|c|c|c|c|}
\hline \multirow[t]{2}{*}{ Variable } & \multicolumn{3}{|c|}{ At baseline } & \multicolumn{3}{|c|}{ Week 32} & \multirow[b]{2}{*}{$p$} \\
\hline & Mean \pm SD & Median & Min.-max. & Mean \pm SD & Median & Min.-max. & \\
\hline Hemoglobin level (gm/dl) & $13.8 \pm 1.7$ & 14.1 & $9.6-16.7$ & $14.3 \pm 1.6$ & 14.9 & $9.9-18.2$ & 0.001 \\
\hline Erythrocyte sedimentation rates $(\mathrm{mm} / \mathrm{h})$ & $35.7 \pm 31.2$ & & & $13.2 \pm 21.7$ & & & $<0.001$ \\
\hline C-reactive protein $(\mathrm{mg} / \mathrm{L})$ & $20.8 \pm 30.3$ & & & $4.5 \pm 11.5$ & & & $<0.001$ \\
\hline BASDAI score & $6.7 \pm 1.4$ & & & $2.6 \pm 1.5$ & & & $<0.001$ \\
\hline
\end{tabular}

hemoglobin level was $11.6 \pm 0.9 \mathrm{gm} / \mathrm{dl}$. Of these, four of the twelve showed an ACD pattern and eight showed an IDA pattern (mean hemoglobin level 11.8 \pm 1.5 and $11.6 \pm 0.7 \mathrm{gm} / \mathrm{dl}$, respectively). Only one female patient with an ACD pattern had severe anemia (hemoglobin level $<10 \mathrm{gm} / \mathrm{dl}$ ). Among the patients with an IDA pattern, three female patients with a hemoglobin level below $10 \mathrm{gm} / \mathrm{dl}$ received an iron supplement. This data suggests that anemia is not uncommon in patients with AS, especially with increased disease activity.

\section{Effects of anti-TNF therapy on hemoglobin level and clinical assessments at week 32}

Patients who received anti-TNF agents demonstrated statistically significant reductions in their ESR, CRP and BASDAI scores at week 32 when compared with the baseline. The mean hemoglobin levels also significantly improved from 13.8 to $14.3 \mathrm{gm} / \mathrm{dl}(\mathrm{p}=0.001)$ (Table 2).

To evaluate the independent effects of clinical and laboratory variables on the improvement in hemoglobin levels, we analyzed the regression of the contribution of the clinical and laboratory variables by using a multivariate regression model. The differences in the ESR and CRP affected the differences in hemoglobin independently $(p=0.007$ and $p=0.010$, respectively) (Table 3). The change in hemoglobin levels showed a positive correlation with the differences in the ESR

Table 3. Association between clinical and laboratory variables and differences in hemoglobin

\begin{tabular}{lcc}
\hline Variable & Beta & $p$ \\
\hline Sex & -0.119 & 0.331 \\
Age (years) & -0.013 & 0.919 \\
Disease duration (years) & 0.099 & 0.436 \\
Type of anti-TNF agents & -0.086 & 0.488 \\
$\Delta$ BASDAI & 0.180 & 0.131 \\
$\Delta$ ESR & 0.405 & 0.007 \\
$\Delta$ CRP & 0.383 & 0.010 \\
\hline BASDAI: Bath Ankylosing Spondylitis Disease Activity Index; ESR: \\
Erythrocyte sedimentation rates; CRP: C-reactive protein; TNF: Tumor \\
necrosis factor-alpha; ${ }^{2}=0.547$.
\end{tabular}

and CRP ( $\mathrm{r}=0.608, \mathrm{p}<0.001$ and $\mathrm{r}=0.588, \mathrm{p}<0.001$, respectively) (Figure 2). This result suggests that in AS, systemic inflammation affects the hemoglobin levels. These could be improved by the effective suppression of inflammation.

\section{Improvement of hemoglobin levels in ACD with anti-TNF therapy}

Ankylosing spondylitis patients with anemia were divided into groups with ACD and IDA based on the criteria of previously reported data, ${ }^{[15,16]}$ and we investigated the changes in hemoglobin levels according to anemia type. The hemoglobin levels at baseline and week 32 are shown in Figure 3. In patients with ACD, significant improvement in the hemoglobin levels (from $11.8 \pm 1.5 \mathrm{gm} / \mathrm{dl}$ to $13.7 \pm 1.7 \mathrm{gm} / \mathrm{dl}$ ) were observed $(p=0.010)$. In patients with IDA, the hemoglobin levels increased from $11.6 \pm 0.7 \mathrm{gm} / \mathrm{dl}$ to $12.4 \pm 1.7 \mathrm{gm} / \mathrm{dl}$ but did not reach statistical significance $(\mathrm{p}=0.079)$. Even in non-anemic patients, an increase in the hemoglobin level (from $14.7 \pm 1.0 \mathrm{gm} / \mathrm{dl}$ to $15.0 \pm 1.2 \mathrm{gm} / \mathrm{dl}$ ) was observed, and it was statistically significant, albeit minimally $(\mathrm{p}<0.05)$. The anemia was resolved in all patients with ACD except for one, whereas only three patients with IDA recovered from their anemia. Among the three IDA patients receiving an iron supplement, improvement in hemoglobin levels was seen in only one case.

Hemoglobin concentration was corrected in only one patient with an IDA pattern in that assessment period.

We compared the effects of anti-TNF therapy on hemoglobin levels with that of DMARD therapy in the same patients before anti-TNF therapy. In DMARD therapy, the hemoglobin levels, ESR, and CRP at baseline and week 32 were assessed. Twelve patients were also found to have anemia, and four of them showed an ACD pattern at baseline. After a period of DMARD therapy, the hemoglobin level increased from $13.3 \pm 1.9$ to $13.7 \pm 1.6 \mathrm{gm} / \mathrm{dl}$ $(\mathrm{p}=0.008)$ ans was accompanied by a decrease in 

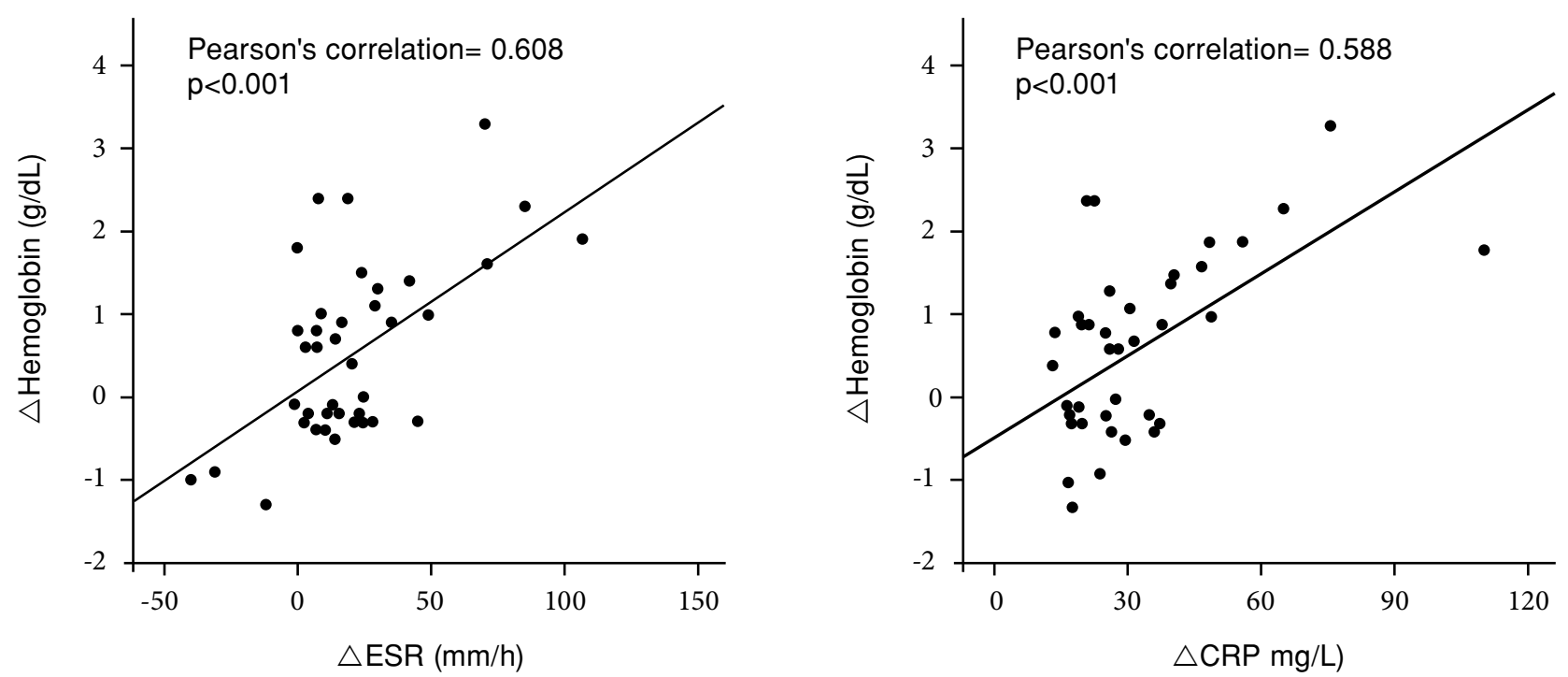

Figure 2. The relationship between the differences in the erythrocyte sedimentation rates (ESR) and C-reactive protein (CRP) along with the differences in hemoglobin levels in ankylosing spondylitis patients receiving anti-tumor necrosis factor therapy.

the ESR $(47 \pm 31$ to $23 \pm 21 \mathrm{~mm} / \mathrm{h}, \mathrm{p}<0.001)$ and CRP $(25.4 \pm 29.8$ to $9.4 \pm 12.2 \mathrm{mg} / \mathrm{L}, \mathrm{p}<0.001)$. There was a tendency for the differences in hemoglobin levels in anti-TNF therapy to be a little higher than those in DMARD therapy, but this was not statistically significant $(\mathrm{p}=0.436)$. However, in patients with ACD, the effects of anti-TNF therapy on improvement in hemoglobin levels was more significant than for DMARD therapy $(1.8 \pm 0.6$ versus $0.6 \pm 0.5, \mathrm{p}=0.023)$ (Figure 4).

These results demonstrate that improvement in hemoglobin levels is observed along with an effective suppression of inflammation in patients with AS, and anti-TNF therapy is more effective than DMARDs with regard to improving the hemoglobin levels, especially in patients with ACD.

\section{DISCUSSION}

Anemia of chronic disease is the second most prevalent form after that caused by iron deficiency and develops as a result of acute or a chronic activation of immune response. ${ }^{[1]}$ Anemia of chronic disease is a significant part of anemia in chronic inflammatory conditions like infection, cancer, and autoimmune diseases. ${ }^{[1]}$ However, even though AS is a chronic inflammatory disease, the prevalence and incidence of anemia in AS have not been thoroughly studied. This is probably because AS develops mainly in young men, so mild anemia is often disregarded and not investigated sufficiently to establish the cause. Because TNF- $\alpha$, the predominant proinflammatory cytokine, is central to the pathogenesis of $\mathrm{AS}^{[11]}$ and also plays a major role in the pathogenesis of $\mathrm{ACD},{ }^{[1]}$ this disease could be one of the clinical manifestations of the pathophysiological results in AS.

The first comprehensive study on anemia in patients with AS was reported in 2009 by Braun et al. ${ }^{[17]}$

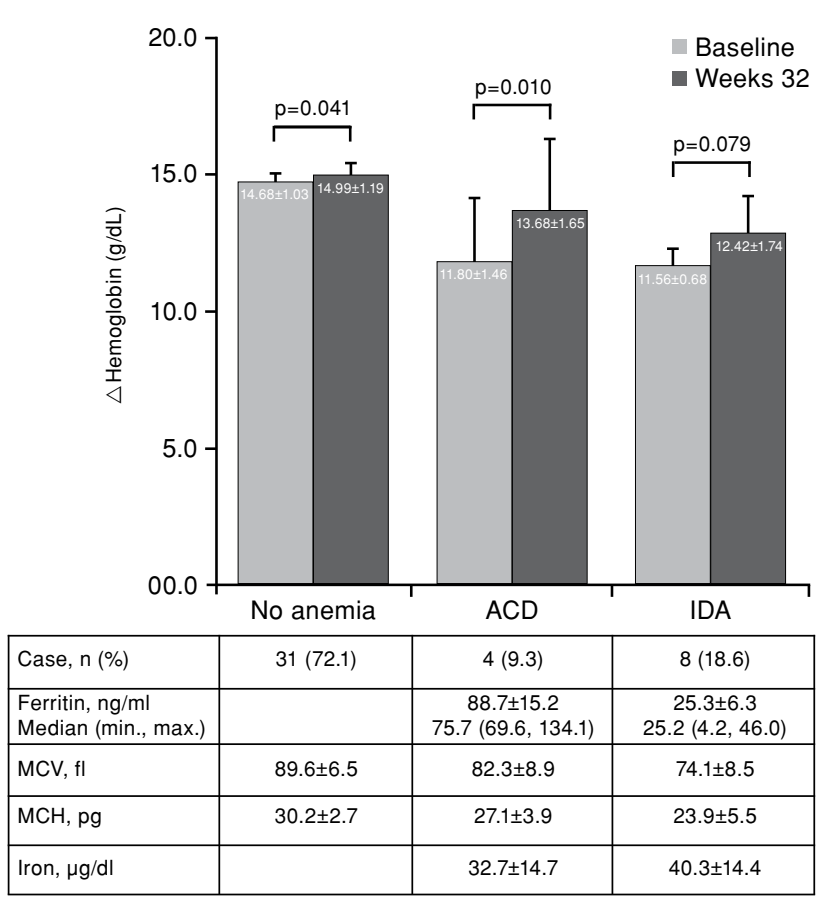

Figure 3. Change in hemoglobin levels according to the type of anemia. ACD: Anemia of chronic disease; IDA: Iron deficiency anemia; MCV: Mean corpuscular volume; MCH: Mean corpuscular hemoglobin. Values are expressed as mean \pm standard deviation. 

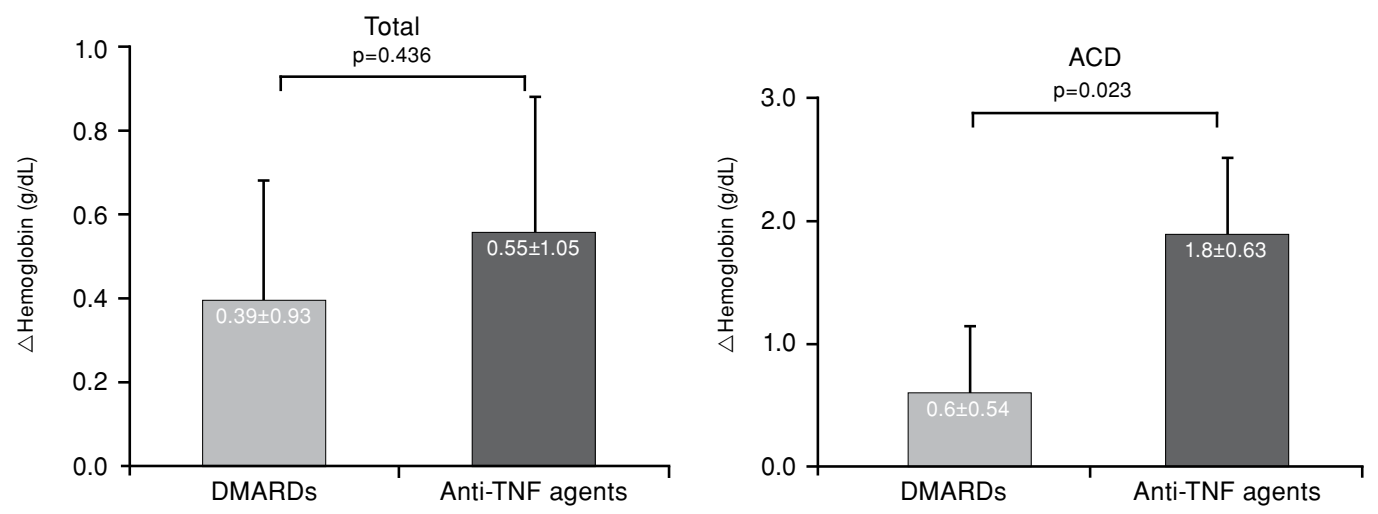

Figure 4. Differences in hemoglobin levels according to treatment modality. Values are expressed as mean \pm standard deviation; ACD: Anemia of chronic disease.

In that study, nearly $20 \%$ of patients had anemia, and anti-TNF therapy significantly decreased the proportion of AS patients with anemia and improved hemoglobin levels. Because data on serum ferritin and iron levels was not collected, the specific cause of anemia could not be determined. However, improvement in hemoglobin levels was much more significant in the ASAS20 responders with anemia at baseline, and elevated levels of the CRP or interleukin-6 (IL-6) at baseline were associated with improvement in hemoglobin levels. These results suggest that the positive effect of anti-TNF therapy on anemia is due to a systemic anti-inflammatory effect. In the present study, $27.9 \%$ of AS patients had anemia. Though the patients were in the active state of disease before the beginning of anti-TNF therapy, this estimated prevalence is comparable to that of other chronic inflammatory diseases, ${ }^{[1]}$ and significant improvement in hemoglobin levels was observed following anti-TNF therapy. Even though there was only a minimal difference $(0.3 \pm 0.8 \mathrm{gm} / \mathrm{dl})$, the hemoglobin levels of patients without anemia also improved significantly, which suggests that the erythropoietic process is suppressed subclinically, even in patients without definite anemia. In patients with anemia, there were conflicting results according to the type of anemia. Significant improvement in hemoglobin levels was noted in patients with ACD but not in patients with IDA. Iron deficiency anemia improved modestly but was not corrected with anti-TNF therapy. Anemia of chronic disease probably contributed to anemia development to some extent in patients with IDA, but there was a limit to the improvement of anemia in patients with iron deficiency. These findings are consistent with the previous observations regarding RA patients following anti-TNF therapy. ${ }^{[16]}$

We found that improvement in hemoglobin levels was significantly associated with decreases in the ESR and CRP, and this was independent of improvement in disease activity (BASDAI score). The higher levels in hemoglobin showed a positive correlation with the lower levels of the ESR and CRP, which is consistent with previous observations. ${ }^{[5]}$ Tumor necrosis factoralpha induces the production of IL-6 from the inflammatory cells, and these two together stimulate the production of most acute-phase proteins, such as CRP, serum amyloid A, and fibrinogen as well as hepcidin from hepatocytes. Fibrinogen, the most abundant acute-phase protein, has the greatest effect on the elevation of the ESR..$^{[1,18-20]}$ Moreover, in anemia, with the hematocrit reduced, the velocity of the upward flow of plasma is altered so that red blood cell aggregates fall faster, leading to elevation of the ESR. ${ }^{[21]}$ Therefore relationship between the ESR, CRP, and hemoglobin levels is a clinical mirror of the pathophysiological dynamics between inflammation and anemia.

All patients enrolled in this study were treated with NSAIDs and/or DMARDs such as sulfasalazine and/or MTX before the anti-TNF therapy for a certain period of time and exhibited clinical and laboratory improvement. Although the hemoglobin levels improved in both the DMARD and anti-TNF therapy in patients with ACD, the results of the anti-TNF therapy were superior to those of the DMARD therapy. Similar findings were also observed in clinical studies of patients with RA being treated with infliximab. ${ }^{[22]}$ This suggests that TNF- $\alpha$ is the more direct factor involved in the development of ACD in AS. In the 
research of ACD in RA, the administration of a TNF- $\alpha$ blockade led to an increase in hemoglobin levels which were independent of erythropoietin production. ${ }^{[23]}$ Rheumatoid arthritis patients exhibited low frequency and increased apoptosis of the bone marrow erythroid progenitor and precursor cells due to increased local production of TNF- $\alpha .{ }^{[16]}$ Additionally, in the patients with RA, the serum hepcidin levels were positively correlated with disease activity but inversely correlated with hemoglobin levels. ${ }^{[24]}$ Therefore, it is thought that anti-TNF therapy dampers TNF- $\alpha$-induced accelerated apoptosis of bone marrow erythroid cells and hepcidin production, which in turn contributes to the pathogenesis of ACD in AS as well as in RA.

Most patients included in this study were taking NSAIDs, and this was maintained throughout the duration of the anti-TNF therapy. This is probably because NSAIDs are the only drugs currently known to reduce radiographic progression in symptomatic patients with AS. ${ }^{[25]}$ Disease-modifying anti-rheumatic drugs potentially can cause gastrointestinal bleeding, but only one case developed a duodenal ulcer in a randomized trial of 215 AS patients, ${ }^{[25]}$ and no remarkable evidence of bleeding was observed in this retrospective study. Five patients with IDA observed in this study were fertile females, and the cause of IDA was considered to be attributable to menstruation. However, the possibility of subclinical mucosal injury and hemorrhage in patients taking NSAIDs could not be excluded. ${ }^{[26]}$ It has now been proven that MTX is not effective for the axial manifestation in AS, but it was commonly prescribed prior to the introduction of anti-TNF agents. ${ }^{[27]}$ There has been no report regarding such adverse effects as bone marrow suppression and gastrointestinal injury in clinical studies for the efficacy of MTX in AS. ${ }^{[28-30]}$ Moreover, the addition of MTX to infliximab did not provide additional benefits to AS treatment and was just as safe and effective as infliximab monotherapy. ${ }^{[30]}$ Therefore, MTX might not have an essential effect on the pathobiology of AS.

In general, anemia is not considered to be a major problem in AS by the vast majority of physicians. This statement is based on the fact that studies on anemia in AS are sparse. This study had some limitations with regard to small sample size and insufficient data on anemia. Nevertheless, the results presented here demonstrate that anemia is not uncommon in AS patients, especially in those with increased disease or inflammatory activity. Our study also showed the potential effects of anti-TNF therapy on the pathophysiology of ACD in these patients. Improvement in hemoglobin levels would be an interesting and beneficial secondary benefit for patients who are candidates for anti-TNF therapy. Further larger and prospective studies will undoubtedly contribute to our understanding of the pathogenesis of AS-associated anemia and possibly reveal more about the role of the TNF- $\alpha$ blockade.

\section{Declaration of conflicting interests}

The authors declared no conflicts of interest with respect to the authorship and/or publication of this article.

\section{Funding}

The authors received no financial support for the research and/or authorship of this article.

\section{REFERENCES}

1. Weiss G, Goodnough LT. Anemia of chronic disease. N Engl J Med 2005;352:1011-23.

2. Dallman PR, Yip R, Johnson C. Prevalence and causes of anemia in the United States, 1976 to 1980. Am J Clin Nutr 1984;39:437-45.

3. Zarychanski R, Houston DS. Anemia of chronic disease: a harmful disorder or an adaptive, beneficial response? CMAJ 2008;179:333-7.

4. Baer AN, Dessypris EN, Goldwasser E, Krantz SB. Blunted erythropoietin response to anaemia in rheumatoid arthritis. Br J Haematol 1987;66:559-64.

5. Wolfe F, Michaud K. Anemia and renal function in patients with rheumatoid arthritis. J Rheumatol 2006;33:1516-22.

6. Peeters HR, Jongen-Lavrencic M, Raja AN, Ramdin HS, Vreugdenhil G, Breedveld FC, et al. Course and characteristics of anaemia in patients with rheumatoid arthritis of recent onset. Ann Rheum Dis 1996;55:162-8.

7. Peeters HR, Jongen-Lavrencic M, Bakker CH, Vreugdenhil G, Breedveld FC, Swaak AJ. Recombinant human erythropoietin improves health-related quality of life in patients with rheumatoid arthritis and anaemia of chronic disease; utility measures correlate strongly with disease activity measures. Rheumatol Int 1999;18:201-6.

8. Straus DJ, Testa MA, Sarokhan BJ, Czuczman MS, Tulpule A, Turner RR, et al. Quality-of-life and health benefits of early treatment of mild anemia: a randomized trial of epoetin alfa in patients receiving chemotherapy for hematologic malignancies. Cancer 2006;107:1909-17.

9. Tam LS, Gu J, Yu D. Pathogenesis of ankylosing spondylitis. Nat Rev Rheumatol 2010;6:399-405.

10. Elewaut D, Matucci-Cerinic M. Treatment of ankylosing spondylitis and extra-articular manifestations in everyday rheumatology practice. Rheumatology (Oxford) 2009;48:1029-35.

11. Henderson C, Davis JC. Drug insight: anti-tumornecrosis-factor therapy for ankylosing spondylitis. Nat Clin Pract Rheumatol 2006;2:211-8. 
12. van der Linden S, Valkenburg HA, Cats A. Evaluation of diagnostic criteria for ankylosing spondylitis. A proposal for modification of the New York criteria. Arthritis Rheum 1984;27:361-8.

13. Braun J, Davis J, Dougados M, Sieper J, van der Linden S, van der Heijde D, et al. First update of the international ASAS consensus statement for the use of anti-TNF agents in patients with ankylosing spondylitis. Ann Rheum Dis 2006;65:316-20.

14. Beutler E, Waalen J. The definition of anemia: what is the lower limit of normal of the blood hemoglobin concentration? Blood 2006;107:1747-50.

15. Vreugdenhil G, Baltus CA, van Eijk HG, Swaak AJ. Anaemia of chronic disease: diagnostic significance of erythrocyte and serological parameters in iron deficient rheumatoid arthritis patients. Br J Rheumatol 1990;29:105-10.

16. Papadaki HA, Kritikos HD, Valatas V, Boumpas DT, Eliopoulos GD. Anemia of chronic disease in rheumatoid arthritis is associated with increased apoptosis of bone marrow erythroid cells: improvement following antitumor necrosis factor-alpha antibody therapy. Blood 2002;100:474-82.

17. Braun J, van der Heijde D, Doyle MK, Han C, Deodhar $\mathrm{A}$, Inman $\mathrm{R}$, et al. Improvement in hemoglobin levels in patients with ankylosing spondylitis treated with infliximab. Arthritis Rheum 2009;61:1032-6.

18. Brennan FM, McInnes IB. Evidence that cytokines play a role in rheumatoid arthritis. J Clin Invest 2008;118:3537-45.

19. Gabay C, Kushner I. Acute-phase proteins and other systemic responses to inflammation. $\mathrm{N}$ Engl J Med 1999;340:448-54.

20. Pepys MB, Hirschfield GM. C-reactive protein: a critical update. J Clin Invest 2003;111:1805-12.

21. Brigden ML. Clinical utility of the erythrocyte sedimentation rate. Am Fam Physician 1999;60:1443-50.

22. Doyle MK, Rahman MU, Han C, Han J, Giles J, Bingham CO 3rd, et al. Treatment with infliximab plus methotrexate improves anemia in patients with rheumatoid arthritis independent of improvement in other clinical outcome measures-a pooled analysis from three large, multicenter, double-blind, randomized clinical trials. Semin Arthritis Rheum 2009;39:123-31.

23. Davis D, Charles PJ, Potter A, Feldmann M, Maini RN, Elliott MJ. Anaemia of chronic disease in rheumatoid arthritis: in vivo effects of tumour necrosis factor alpha blockade. Br J Rheumatol 1997;36:950-6.

24. Demirag MD, Haznedaroglu S, Sancak B, Konca C, Gulbahar O, Ozturk MA, et al. Circulating hepcidin in the crossroads of anemia and inflammation associated with rheumatoid arthritis. Intern Med 2009;48:421-6.

25. Wanders A, Heijde D, Landewé R, Béhier JM, Calin A, Olivieri I, et al. Nonsteroidal antiinflammatory drugs reduce radiographic progression in patients with ankylosing spondylitis: a randomized clinical trial. Arthritis Rheum 2005;52:1756-65.

26. Strom BL, Taragin MI, Carson JL. Gastrointestinal bleeding from the nonsteroidal anti-inflammatory drugs. Agents Actions Suppl 1990;29:27-38.

27. Haibel H, Sieper J. Use of methotrexate in patients with ankylosing spondylitis. Clin Exp Rheumatol 2010;28:S128-31.

28. Gonzalez-Lopez L, Garcia-Gonzalez A, Vazquez-DelMercado M, Muñoz-Valle JF, Gamez-Nava JI. Efficacy of methotrexate in ankylosing spondylitis: a randomized, double blind, placebo controlled trial. J Rheumatol 2004;31:1568-74.

29. Haibel H, Brandt HC, Song IH, Brandt A, Listing J, Rudwaleit $M$, et al. No efficacy of subcutaneous methotrexate in active ankylosing spondylitis: a 16-week open-label trial. Ann Rheum Dis 2007;66:419-21.

30. Li EK, Griffith JF, Lee VW, Wang YX, Li TK, Lee KK, Tam LS. Short-term efficacy of combination methotrexate and infliximab in patients with ankylosing spondylitis: a clinical and magnetic resonance imaging correlation. Rheumatology (Oxford) 2008 ;47:1358-63. 